\title{
Severe congenital nemaline myopathy
}

INSERM

\section{Source}

INSERM. (1999). Orphanet: an online rare disease and orphan drug data base. Severe congenital nemaline myopathy. ORPHA:171430

Severe congenital nemaline myopathy is a severe form of nemaline myopathy (NM; see this term) characterized by severe hypotonia with little spontaneous movement in neonates. 